\title{
"A Study On The Sustainable Investment Funds With Sepcial Reference To State Bank Of India Esg Mutual Fund Shcemes"
}

\section{Dr. A. Anis Akthar Sulthana Banu, Dr.T.S. Bhuvaneswari, Dr. SAJIDA BEGUM.K}

${ }^{1}$ Associate Professor, Department of B. Com (CS) \& Information Systems ManagementJustice Basheer Ahmed Sayeed College for Women (Autonomous)(AN), Teynampet, Chennai. Email id:anisakthar1974@gmail.com

${ }^{2}$ Associate Professor, Coordinator, Department of Commerce Saveetha College of Liberal Arts and Sciences, Thandalam. Email id: bhuvaneswari.acc@gmail.com

${ }^{3}$ Assistant Professor, Department of Commerce,Justice Basheer Ahmed Sayeed College for Women (FN), Teynampet, Chennai.Email id:sajidajbas@gmail.com

Article History:Received:11 november 2020; Accepted: 27 December 2020; Published online: 05 April 2021

ABSTRACT:Socially Responsible Investment (SRI) refers to the allocation of funds in certain practises that have a high social impact. It includes assessing businesses on the Environmental, Social and Governance (ESG) screens. A socially conscious investor may either invest directly in financial markets or through investment instruments such as mutual funds via ESG fund schemes. Very few of the numerous mutual fund organizations have implemented ESG Fund schemes to appeal to SRI investors. The SBI Mutual Fund is the first AMC to follow this and has been benchmarked against the Nifty 100 ESG indices. A correlation analysis is made among the results of the SBI Mutual Fund and the NIFTY to compare the four different types of SBI ESG funds and their sector wise participation in different industries. This research paper is methodological in nature as it interprets the published secondary data sources of the SBI Mutual Fund and the NIFTY indices. The goal of this paper is to assess the efficacy of the ESG Equity Fund in the investment portfolio of mutual fund investors and to enable small and medium-sized investors to contribute their money to ESG-driven mutual fund schemes.

Keywords: Environmental-Social- Governance, Sri, Ethical Investing, Non-Financial Performance.

\section{INTRODUCTION}

In recent periods, "socially aware" investing has become a widely-followed trend and an growing number of investors are keen to see their funds go in the direction of stocks or funds that are both efficient and representative of their social values. Three investment approaches have accomplished this: Environmental, Social and Governance (ESG), Socially Responsible Investment (SRI) and Socially Responsible Investment (SRI), in combination with more traditional financial controls. Socially responsible investing leads dynamically to the exclusion or selection of investments based on established moral criteria. Impact Investment aims to inspire an enterprise to complete a mission or to establish a programme or to do something meaningful to support society.

There are plenty of new funds and mutual investing mechanisms open to institutional investors. Mutual funds and ETFs have an additional benefit that customers can gain exposure to several businesses across a wide variety of markets through a single investment.

"ESG is a broad subject, and while fossil fuel concerns are one of the most common factors, there are a number of other indicators through ESG," "Other environmental metrics of concern include water consumption, clean energy projects and the nature of a specific environmental policy programme. "-Goldman Sachs Asset Management.

The SBI Mutual Fund was founded in 1987 as a partnership between SBI and AMUNDI (France), one of the world's leading fund management firms. The SBI Magnum Equity Fund was launched in 1991. SBI is the first wealth management firm in India to initiate an Climate, Social and Governance ( ESG) fund for the Magnum Equity ESG Fund in 2018 and has also signed the United Nations Responsible Investment Principles (UN-PRI). Through the four separate ESG Mutual Fund schemes, SBI draws investors and adds to the wellbeing of the country by creating more ESG investors willing to invest in responsible firms, a comparative study is undertaken with NIFTY 100 ESG Indices to assess the value of the Sectoral Portfolio Distribution and Investment Returns.

\section{REVIEW OF LITERATURE}

*Corresponding author: Dr. A. Anis Akthar Sulthana Banu

Associate Professor, Department of B. Com (CS) \& Information Systems Management

Justice Basheer Ahmed Sayeed College for Women (Autonomous)(AN), Teynampet, Chennai.

Email id:anisakthar1974@gmail.com 
Arphana.D (2013): India's incursion into benchmarking SRI was made when the S \& P ESG index was founded by S\&P \& CRISIL. The purpose of the index is to assess environmental, social and governance practices based on quantitative rather than subjective criteria The index uses a special and creative approach that quantifies the ESG practices of a organization and transforms them into a scoring formula that is then used to rate each company against its peers in the Indian market. It is necessary to find a balance between the SRI and the client's financial targets without having any unfavorable effect on the future returns. SRI-based mutual funds will be a low-cost choice for institutional investors. It has also been found that businesses that are more socially conscious tend to have higher and more reliable returns than their rivals who do not share the same values. Reliance industries, Wipro, Aditya Birla Nuvo, Bharti, HDFC are all components of the S\&P ESG index. Any observer would regard problems of corporate governance, environmental sustainability, corruption, health and welfare, etc. as critical components of good governance and a predictor of promising financial success. In the future, teams of financial analysts and SRI analysts will work together to build portfolios.

Gunnar Friede, Timo Buschand Alexander Bassen (2015) Combined the results of 2200 different research to assess the financial consequences of the ESG criterion and reported that $90 \%$ of the studies found a non-negative ESG - CFP (Corporate Financial Performance) relationship. Most prominently, the vast majority of experiments have revealed positive results. We stress that the positive effect of the ESG on the CFP is, in due course, evident. CFP indicators are claimed to be success dependent on accounting, business, operating, perceptual, growth metrics, risk measures, and ESG portfolios performance. The study concluded that the emphasis on long-term prudent investment should be essential for lucid investors to satisfy their fiduciary responsibilities and to properly balance the interests of investors with the larger goals of society. This includes a detailed and informative perspective into how ESG parameters should be integrated into investment procedures in order to reap the full potential of value-enhancing ESG variables. A main area for future study is a clearer understanding of the interaction of various ESG parameters in portfolios and the importance of particular ESG sub-criteria for CFP.

Dirk Schoenmaker \& Willem Schramade (2019) revealed the need for the Adaptive Markets Hypothesis (AMH) that offers an alternate definition of markets. Prices represent as much knowledge as is determined by the mixture of environmental factors and the number and scope of different classes of market actors, each working in a similar fashion and possessing a common investment horizon. The adaptive market theory may clarify how emerging risks, such as environmental risks, are not yet completely priced. Performance on Particular Main Performance Measures (KPIs) and commitment to global development targets are two ways of doing non-financial performance assessment. The researcher recognizes agile business thinking, short investment chains, and aggressive management in focused portfolios, with a firm effort to evaluate change preparedness aimed at engaging in long-term value growth. Achieving paradigm shift requires a change of mind. Integrated sustainable finance curriculum and governance and regulatory incentives are required for this.

\section{STATEMENT OF THE PROBLEM}

The concern for Environmental protection, Social welfare and Governance to enhance value of shareholders is gaining momentum as a component of ethical investment in financial markets. Though investors aware of various equity schemes they are focusing on return on investment as a priority and build their portfolio by including many Non- ESG companies. Mutual Funds have started to play an active role in attracting small investors to contribute their capital for socially responsible corporations by creating exclusive equity funds that conforms to ESG norms and also build their portfolio sector wise to keep pace with the benchmarking indices such as NIFTY 100 ESG and S\&P BSE. Hence Mutual funds are striving hard to improve the financial gain as well as balancing the risk profile of ESG funds.

\section{SCOPE OF STUDY}

Although the study is global in perspective, the study is restricted to Indian capital markets for the purpose of a research survey and review. Various investing platforms The mutual funds are used for the analysis, taking into account their role and value in pooling contributions from different parts of society. Investments concerned with the environment, the social and the governance sector are considered 58 alone to provide valuable suggestions to investors. The research includes the Magnum Equity ESG Investment schemes of the State Bank of India Mutual Fund and their relation with the Nifty ESG indices.

\section{AIMS OF THE STUDY}

1. To identify the growth of SBI Magnum Mutual Fund schemes with regard to the benchmark indices.

2. To compare the Magnum Equity graded fund schemes for measuring their performance.

3. To suggest effective portfolio of ESG firms for better NAV and investor retention. 


\section{SUPPOSITION OF THE STUDY}

1. There is no significant correlation among the Historical value of Nifty 100 ESG indices and Historical NAV of SBI Magnum ESG Funds for the last 5 years

2. There is no association among the Historical NAVs of 2 paired Samples such as SBI Magnum Equity ESG Fund Regular Plans and ESG Fund Direct Plans.

3. There is no positive link among sector wise portfolio allocation of Nifty 100 ESG indices and SBI Magnum stock fund

\section{LIMITATION OF THE STUDY}

The research is confined to the State Bank of India's Equity Fund schemes in ESG companies only. The research period is from 2015 to 2019, covering NSE ESG indices and SBI Magnum Mutual Fund NAVs. The research field is limited to India. International capital market funding is out of the blueprint.

\section{APPROACHES TO RESEARCH}

The analysis is descriptive in nature and based on the reported secondary data available on the official websites of the State Bank of India Mutual Funds and the National Stock Exchange. Samples taken for the analysis include SBI Magnum Equity Daily Dividend, Regular Growth, Direct Dividend and Direct Growth.

\section{DATA EXAMINATION AND EXPLICATION}

Ho (1): There is no significant association between the Historical data of Nifty 100 ESG indices and Historical NAV of SBI Magnum ESG Funds for the last 5 years

TABLE 1 - ONE WAY ANOVA TO COMPARE THE NET ANNUAL VALUES OF NIFTY 100 ESG INDICES AND SBI MAGNUM ESG FUND

\begin{tabular}{|c|c|c|c|c|c|c|}
\hline \multicolumn{7}{|c|}{ ANOVA } \\
\hline & & $\begin{array}{c}\text { Sum of } \\
\text { Squares }\end{array}$ & df & Mean Square & $\mathrm{F}$ & Sig. \\
\hline \multirow{3}{*}{$\begin{array}{l}\text { SBI Magnum Equity ESG Fund -Regular } \\
\text { Dividend }\end{array}$} & Between Groups & 6997.233 & 1214 & 5.764 & .855 & .683 \\
\hline & Within Groups & 47.211 & 7 & 6.744 & & \\
\hline & Total & 7044.444 & 1221 & & & \\
\hline \multirow[t]{3}{*}{ SBI Magnum Equity ESG Fund -Regular Growth } & Between Groups & 186070.774 & 1214 & 153.271 & 23.360 & .000 \\
\hline & Within Groups & 45.929 & 7 & 6.561 & & \\
\hline & Total & 186116.703 & 1221 & & & \\
\hline \multirow[t]{3}{*}{ SB Magnum Equity ESG Fund- Direct Dividend } & Between Groups & 9387.387 & 1214 & 7.733 & .985 & .582 \\
\hline & Within Groups & 54.953 & 7 & 7.850 & & \\
\hline & Total & 9442.340 & 1221 & & & \\
\hline \multirow[t]{3}{*}{ SBI Magnum Equity ESG Fund- Direct Growth } & Between Groups & 233313.914 & 1214 & 192.186 & 22.072 & .000 \\
\hline & Within Groups & 60.950 & 7 & 8.707 & & \\
\hline & Total & 233374.864 & 1221 & & & \\
\hline
\end{tabular}

INFERENCE:

a. There exists a significant relationship between the indices of Nifty 100 ESG Funds and SBI Magnum ESG Funds of Regular Growth and Direct Growth plans as the p value is 0.00 that is less than 0.05 i.e. Null Hypothesis is summarily rejected that proved to be statistically significant.

b. There is no association between Nifty 100 ESG Indices and SBI Magnum ESG Funds of Regular Dividend and Direct Dividend as the $\mathrm{p}$ values are 0.683 and 0.582 that are more than 0.05 i.e. Null hypothesis is accepted and proved to be statistically insignificant.

Ho (2): The Net Annual Values of SBI Magnum Equity ESG Fund Regular Plans and ESG Fund Direct Plans are not closely correlated.

\begin{tabular}{|c|c|c|c|c|}
\hline \multicolumn{5}{|c|}{ TABLE3: PAIRED SAMPLES CORRELATIONS } \\
\hline & & $\mathrm{N}$ & Correlation & Sig. \\
\hline Pair 1 & $\begin{array}{l}\text { SBI Magnum Equity ESG Fund -Regular Dividend } \\
\& \\
\text { SBI Magnum Equity ESG Fund -Regular Growth }\end{array}$ & 1222 & .136 & .000 \\
\hline
\end{tabular}




\begin{tabular}{|c|c|c|c|c|}
\hline \multicolumn{5}{|c|}{ TABLE3: PAIRED SAMPLES CORRELATIONS } \\
\hline & & $\mathrm{N}$ & Correlation & Sig. \\
\hline Pair 1 & $\begin{array}{l}\text { SBI Magnum Equity ESG Fund -Regular Dividend } \\
\& \\
\text { SBI Magnum Equity ESG Fund -Regular Growth }\end{array}$ & 1222 & .136 & .000 \\
\hline Pair 2 & $\begin{array}{l}\text { SB Magnum Equity ESG Fund- Direct Dividend \& } \\
\text { SBI Magnum Equity ESG Fund- Direct Growth }\end{array}$ & 1222 & .305 & .000 \\
\hline
\end{tabular}

\begin{tabular}{|c|c|c|c|c|c|c|c|c|c|}
\hline \multicolumn{10}{|c|}{ TABLE4: PAIRED SAMPLES TEST } \\
\hline & & \multicolumn{5}{|c|}{ Paired Differences } & \multirow[b]{3}{*}{$\mathrm{t}$} & \multirow[b]{3}{*}{$\mathrm{df}$} & \multirow{3}{*}{$\begin{array}{l}\text { Sig. (2- } \\
\text { tailed) }\end{array}$} \\
\hline & & \multirow[b]{2}{*}{ Mean } & \multirow{2}{*}{$\begin{array}{c}\text { Std. } \\
\text { Deviation }\end{array}$} & \multirow{2}{*}{$\begin{array}{l}\text { Std. } \\
\text { Error } \\
\text { Mean }\end{array}$} & \multicolumn{2}{|c|}{$\begin{array}{l}95 \% \text { Confidence } \\
\text { Interval of the } \\
\text { Difference }\end{array}$} & & & \\
\hline & & & & & Lower & Upper & & & \\
\hline $\begin{array}{l}\text { Pair } \\
1\end{array}$ & $\begin{array}{l}\text { SBI Magnum Equity ESG } \\
\text { Fund -Regular Dividend SBI } \\
\text { Magnum Equity ESG Fund - } \\
\text { Regular Growth }\end{array}$ & 56.31 & 12.25 & .35052 & -57.00 & -55.63 & $\begin{array}{r}- \\
160.65\end{array}$ & 1221 & .000 \\
\hline $\begin{array}{l}\text { Pair } \\
2\end{array}$ & $\begin{array}{l}\text { SB Magnum Equity ESG } \\
\text { Fund- Direct Dividend } \\
\text { SBI Magnum Equity ESG } \\
\text { Fund- Direct Growth }\end{array}$ & $53.46^{-}$ & 13.24 & .37887 & -54.21 & -52.72 & 141.11 & 1221 & .000 \\
\hline
\end{tabular}

\section{INFERENCE:}

From the above-mentioned independent 2 paired t-test samples of SBI magnum ESG Standard and Direct Plans, it is observed that the NAVs are statistically significant among themselves and exhibit a significant association and connexion between the two classes.

Ho (3): There is no positive correlation between sectoral portfolio allocation of Nifty 100 ESG indices and SBI Magnum equity fund

\section{TABLE 4: INDUSTRY WISE PORTFOLIO ALLOCATION OF NIFTY ESG AND SBI MAGNUM ESG}

\begin{tabular}{|l|c|c|}
\hline Sector & Weight -NIFTY (\%) & Weight - SBI (\%) \\
\hline Financial services & 37.97 & 44.38 \\
\hline Information Technology & 14.16 & 9.64 \\
\hline Energy & 13.11 & 9.05 \\
\hline Consumer goods & 10.36 & 9.31 \\
\hline Automobile & 5.49 & 5.75 \\
\hline Construction & 4.24 & 4.07 \\
\hline Pharma & 4.22 & 0.84 \\
\hline Metals & 2.78 & 2.13 \\
\hline Cement \& cement products & 2.76 & 5.02 \\
\hline Telecom & 2.05 & 2.28 \\
\hline Fertilizers \& pesticides & 0.72 & NIL \\
\hline Services & 0.67 & 1.60 \\
\hline Chemicals & 0.47 & NIL \\
\hline Media \& entertainment & 0.35 & NIL \\
\hline Textiles & 0.33 & NIL \\
\hline Industrial manufacturing & 0.32 & 1.45 \\
\hline $\begin{array}{l}\text { Cash, cash equivalents, derivative margin and } \\
\text { others }\end{array}$ & NIL & 4.48 \\
\hline TOTAL & & 100.00 \\
\hline
\end{tabular}

TABLE 5: CORRELATIONS BETWEEN NIFTY AND SBI ESG PORTFOLIO

\begin{tabular}{|c|c|c|}
\hline & Nifty100ESGIndex & SBIMagnumESGFund \\
\hline
\end{tabular}




\begin{tabular}{|ll|r|r|}
\hline Nifty100ESGIndex & Pearson & 1 & $.975^{* *}$ \\
& Correlation & & \\
& Sig. (2-tailed) & 16 & .000 \\
& $\mathrm{~N}$ & $.975^{* *}$ & 16 \\
\hline SBI Magnum ESGFund & Pearson & .000 & 1 \\
& Correlation & 16 & \\
& Sig. (2-tailed) & 16 \\
& $\mathrm{~N}$ & \\
\hline
\end{tabular}

**. Correlation is significant at the 0.01 level (2-tailed).

TABLE 6: KENDALL'S TAU-B AND SPEARMAN'S RHO CORRELATIONS BETWEEN NIFTY AND SBI PORTFOLIO

\begin{tabular}{|c|c|c|c|c|}
\hline & & & $\begin{array}{c}\text { Nifty } \\
\text { 100ESGIndex }\end{array}$ & $\begin{array}{c}\text { SBIMagnumES } \\
\text { GFund }\end{array}$ \\
\hline \multirow[t]{6}{*}{ Kendall's tau_b } & \multirow[t]{3}{*}{ Nifty 100ESGIndex } & Correlation Coefficient & 1.000 & $.735^{* *}$ \\
\hline & & \begin{tabular}{|l|} 
Sig. (2-tailed) \\
\end{tabular} & & .000 \\
\hline & & $\mathrm{N}$ & 16 & 16 \\
\hline & \multirow{3}{*}{ SBI Magnum ESGFund } & Correlation Coefficient & $.735^{* *}$ & 1.000 \\
\hline & & \begin{tabular}{|l|} 
Sig. (2-tailed) \\
\end{tabular} & .000 & \\
\hline & & $\mathrm{N}$ & 16 & 16 \\
\hline \multirow[t]{6}{*}{ Spearman's rho } & \multirow[t]{3}{*}{ Nifty100ESGIndex } & Correlation Coefficient & 1.000 & $.873^{* *}$ \\
\hline & & \begin{tabular}{|l|} 
Sig. (2-tailed) \\
\end{tabular} & & .000 \\
\hline & & $\mathrm{N}$ & 16 & 16 \\
\hline & \multirow[t]{3}{*}{ SBI Magnum ESG Fund } & Correlation Coefficient & $.873^{* *}$ & 1.000 \\
\hline & & \begin{tabular}{|l|} 
Sig. (2-tailed) \\
\end{tabular} & .000 & \\
\hline & & $\mathrm{N}$ & 16 & 16 \\
\hline
\end{tabular}

There is a surprising degree of partnership between the Nifty and SBI Magnum ESG portfolios seen in the aforementioned table ( 0.975 - Pearson; 0.765 - Kendall's tau-b and 0.873 - Spearman's rho). The sig values $(.0000)$ are also well proven.

\section{FINDINGS}

Based on the study and perception, it has been known that the SBI Magnum Equity Growth Fund is substantially linked to the NIFTY 100 indices of the ESG firms. It shows the success of the Growth Fund, which travels close to the successful portfolio of NSE 100 ESG firms. Both Normal Growth and Direct Growth Funds are closely correlated, with comparable risk and return profiles. Whereas the Dividend Fund schemes are not strongly associated with NIFTY values and suggests changes that need to be made in the structuring of portfolios.

\section{SUGGESTIONS}

A analysis of SBI Magnum Mutual Investment schemes with index NIFTY indexes reveals the sector 's smart distribution of portfolio shifts to the SBI Fund with respect to financial services, information technology and energy sectors. 4.48 per cent of the Capital Distribution and cash equivalents of the SBI Mutual Fund can be diverted to sectors such as Pesticides, Fertilizers, Media and Textiles to a fair degree. The Government could also pass regulations to allow a minimum required allocation of investor capital to the ESG-oriented funds.

\section{CONCLUSION}

The SBI Magnum Equity Mutual Fund offers investors the promise of long-term capital gains through aggressive investment management in a diversified community of companies according to environmental, social and governance (ESG) requirements. The SBI Thematic Fund Schemes of the ESG have been slowly gaining traction over the last five years. Average assets under management (AAUM) grew to 2690.30 crores from 1601.80 crores in the last 5 years, with an annual growth rate of 13.59 per cent in capital appreciation. In order to draw more buyers to the ESG Funds, SBI should create a more successful portfolio and carry out an in-depth analysis of the ESG conformal industries.

\section{REFERENCES}


Arphana.D 2013 “ A Study on SRI \& ESG Investing”, Asian Journal of Research in Business Economics and Management Vol. 3, No. 11, November 2013, pp. 222-230.

Gunnar Friede, Timo Busch \& Alexander Bassen (2015) ESG and financial performance: aggregated evidence from more than 2000 empirical studies, Journal of Sustainable Finance \& Investment, 5:4, 210-233,

Benjamin J. Richardson "Financing Sustainability: The New Transnational Governance of Socially Responsible Investment", yearbook of internationalenvironmental law.

Dirk Schoenmaker \& Willem Schramade (2019) Investing for longterm value creation, Journal of Sustainable Finance \& Investment, 9:4, 356-377,

Dr. L. Krishna veni and t. Prashanth (2013), "performance evaluation of birla sun life mutual funds - selected funds, asian journal of research in banking and finance, volume 3, issue 6 .

Dr. Vanita Tripathi and Varun Bhandari (2016), "Performance Evaluation of Ethical and Conventional Funds - A Study of Taurus Mutual Fund in India”, Financial Markets and Economic Development, Bloomsbury Publishing India. 